\title{
MATERIAŁY
}

Agnieszka Raniszewska-Wyrwa

DOI: 10.14746/BHW.2014.31.9

Instytut Filozofii

Uniwersytet Mikołaja Kopernika w Toruniu

\section{Johna Locke’a koncepcja wychowania moralnego}

\author{
[...] cnota, prawdziwa cnota jest ta wartościa, \\ do której wychowanie powinno uparcie dązyć. [...] \\ Wszelkie inne wartości i zalety powinny jej ustępować \\ i schodzić wobec niej na drugi plan. \\ J. Locke, Myśli o wychowaniu, $\$ 70$.
}

\begin{abstract}
The Concept of John Locke's Moral Upbringing
John Locke was an English philosopher, doctor and politician who also contributed to the development of educational thinking. His school experiences, as well as those acquired in the role of a teacher, were the impulse behind his deliberations on education. The letters to Edward Clarke, forming an answer to Clarke's request that he guide his children's upbringing, provided the opportunity for him to present them. The content that Locke included in his letters was, in time, repeated in Some Thoughts Concerning Education.

The ideas on descent and the limits of human cognition presented in his philosophical works are closely related with his views on education. In An Essay Concerning Human Understanding Locke stated that the human mind at the moment of birth is a blank slate (tabula rasa), which through life is filled by experiences. As a result, he attributed much importance to education - it is an integral part of the process of filling the mind with content, and through this shaping the person. Locke stressed that most people are "good or bad, beneficial or not as a result of their education".

He was convinced that there is an unbreakable connection between three areas of education: the moral, mental and physical. Of those three he considered moral education as the most important. He stressed that the aim of education is to guide a person in such a way that enables them to control their aspirations, desires and affections with the mind - and that such skills are the basis of virtue. According to Locke, without virtue and self-discipline it is difficult to act in a reasonable way.

He recognised people's individualism, so he recommended that the methods of education should be fitted to the abilities of the child. He called for the replacement of orders and prohibitions with explanation, habituation, understanding and experience. A child needs to be taught, among other things, to appreciate truth, honesty, respect for others, kindness and restraint from cruelty towards people and animals. According to Locke, this should lead to correct shaping of moral character.
\end{abstract}

Keywords: John Locke, education, morality, virtue, ethics 


\section{Wprowadzenie}

Harmonijne i wszechstronne kształtowanie osobowości młodego człowieka nie może nie obejmować wychowania moralnego, które zasadza się na wyborze określonych wartości, wyzwalaniu sprawności moralnych, które sa podstawa do czynienia dobra ${ }^{1}$; czy szerzej - stanowi dążenie do uformowania w jednostce postaw i zachowań oraz poważania dla wartości i norm, które są powszechnie akceptowane w danym społeczeństwie. Pomaga ono rozwijać miłość do określonych elementów kultury, które uważa się za szczególnie wartościowe ${ }^{2}$. Heliodor Muszyński przez pojęcie wychowanie moralne rozumie pewien zorganizowany system świadomie i celowo podejmowanych - na przestrzeni określonego czasu - oddziaływań wychowawczych, których zadaniem jest ksztaltować w odpowiedni sposób charakter wychowanka ${ }^{3}$. Podkreśla, że proces ten nierozerwalnie wiąże się z wyborem pewnych wartości, które mają być rozwijane i utrwalane w jednostce. Również Janusz Homplewicz zwraca uwagę, iż dla działalności wychowawczej istotne znaczenie posiada zachowanie pewnych wartości etycznych ${ }^{4}$. Zdaniem Ewy Klimowicz wartość to wszystko to, co cenne, godne pożądania lub wyboru, co stanowi ostateczny cel ludzkich dażeñ . Wartości moralne to wartości uniwersalne, akceptowane przez większość, takie jak sprawiedliwość, dobroć, uczciwość, prawda, odpowiedzialność, życzliwość czy odwaga, stąd też właśnie na nie pragnie się uwrażliwić dziecko w procesie wychowania moralnego, przy czym priorytet można przyznawać różnym wartościom, najczęściej jednak dobru, utożsamianemu z postawą życzliwości dla istot potrzebujących pomocy, i odpowiedzialności rozumianej jako gotowość do dobrowolnego ponoszenia konsekwencji wynikających z własnego postępowania ${ }^{6}$. Mieczysław Łobocki jest zaś zdania, że wartością nadrzędną w wychowaniu powinien być altruizm, przez pojęcie którego rozumie się na ogót bezinteresowna troskę o drugiego czlowieka?.

Wychowanie moralne od dawna stanowiło przedmiot zainteresowania pedagogów i filozofów, którzy rozważali, w jaki sposób wychowywać młodego człowieka, aby wykształcić w nim poszanowanie wartości, zasad i norm moralnych. Problemowi temu wiele uwagi poświęcił również angielski filozof, lekarz i pedagog - John Locke, na kształt myśli pedagogicznej którego istotny wpływ wywarła jego biografia, zwłaszcza zaś okres edukacji.

\footnotetext{
${ }^{1}$ A. Róg, M. Orzechowska, Wychowanie do wartości, „Edukacja i Dialog” 5, 2004, s. 12.

${ }^{2}$ W. Brezinka, Wychowanie i pedagogika $w$ dobie przemian kulturowych, Kraków 2005, s. 26.

3 H. Muszyński, Teoretyczne problemy wychowania moralnego, Warszawa 1965, s. 142.

4 J. Homplewicz, Etyka pedagogiczna, Wydawnictwo Salezjańskie, Warszawa 2000, s. 15.

5 E. Klimowicz, Wartość, w: Słownik etyczny, red. S. Jedynak, Lublin 1990, s. 258.

${ }^{6}$ H. Muszyński, Rozwój moralny, Warszawa 1983, s. 169. Według Krystyny Ryczan w wychowaniu moralnym ważne jest ksztaltowanie postawy społecznej odpowiedzialności. J. Mariański, Kryzys moralny czy transformacja wartości? - studium socjologiczne, Lublin 2001, s. 209.

${ }^{7}$ M. Łobocki, Altruizm w wychowaniu, Lublin 2002, s. 9.
} 


\section{Edukacja i dzialalność Locke’a}

Locke urodził się 29 sierpnia 1632 r. w Wrington, w hrabstwie Somerset w południowo-zachodniej Anglii ${ }^{8}$. Jego matka zmarła, gdy był jeszcze dzieckiem, natomiast z ojcem, prawnikiem i właścicielem ziemskim, nieustannie pochłoniętym obowiązkami, widywał się raczej rzadko. Ojciec Locke’a był człowiekiem surowym (co uwidaczniało się m.in. w jego akceptacji stosowania kar cielesnych dla niezamężnych matek), który żywił przekonanie, że dziecku nie należy pobłażać, lecz utrzymywać je na dystans oraz wykształcić w nim respekt wobec rodziców ${ }^{9}$. Wczesne kształcenie Locke’a odbywało się w domu, a dopiero w wieku 15 lat, w roku 1647, rozpoczął naukę w Westminster School w Londynie. Ponieważ rodzinny majątek uległ znacznemu uszczupleniu, skutkiem czego brakowało środków na opłacenie edukacji, korzystał on z przywileju kształcenia się na koszt skarbu państwa. Zaliczał się do grona tzw. uczniów królewskich, mających zapewnione utrzymanie oraz możliwość zamieszkiwania w szkole. Jako student Locke miał okazję doświadczyć typowych dla XVII w. schematów edukacyjnych przeznaczonych dla dorastających chłopców; obejmowały one ścisłe przestrzeganie reguł, wczesne (godz. 05.15) rozpoczynanie aktywności, surowe kary (chłosta), zapamiętanie zasad gramatyki oraz niezliczonej ilości tekstów łacińskich i greckich.

Pomimo że program i sposób nauczania Locke postrzegał jako nużący i nieciekawy, zaliczał się do grona najlepszych uczniów, dzięki czemu w roku 1652 został skierowany jako stypendysta do kolegium Christ Church w Oxfordzie. W 1656 r. otrzymał tytuł Bachelor of Arts (bakalaureat sztuk), a 29 czerwca 1658 r. - mistrza nauk wyzwolonych. Po ukończeniu studiów pozostał w Oxfordzie i objął stanowisko wykładowcy greki, retoryki i etyki. W 1666 r. Locke rozpoczął studia medyczne, kontynuując jednocześnie wykłady z etyki i filozofii moralnej. W tym samym roku zawarł znajomość z lordem Ashley'em, późniejszym hrabią Shaftesbury, który powierzył mu posadę, początkowo, lekarza rodzinnego (mimo że Locke nie posiadał jeszcze prawa praktyki), z czasem wychowawcy swego syna i osobistego sekretarza. W 1674 r. Locke uzyskał bakalaureat medyczny, a w latach 1675-1677 pełnił funkcję opiekuna i wychowawcy syna Johna Banksa, przyjaciela hrabiego Shaftesbury. Na początku 1683 r., ze względu na swe powiązania polityczne, nie czując się bezpiecznie w Anglii, Locke wyjechał do Holandii; do kraju powrócił po rewolucji angielskiej, w roku 1689. W 1696 został mianowany członkiem Komisji Handlu i Plantacji, z którą związany był do roku 1700, kiedy to z uwagi na pogarszający się stan zdrowia postanowił wycofać się z życia publicznego. Zdecydował się zamieszkać na wsi w okolicach Essex, u córki swego przyjaciela Ralfa Cudwortha, której udzielał rad na temat wychowania dzieci ${ }^{10}$. Zmarł 28 października 1704, został pochowany na cmentarzu kościoła parafialnego w High Laver. Spod pióra Locke’a wyszedł szereg prac, spośród których najbardziej znaczącymi są Rozważania dotyczace rozumu ludzkie-

\footnotetext{
${ }^{8}$ R. Aldrich, John Locke (1632-1704), „Prospects: the quarterly review of education” Vol. 24, No. 1/2, 1994, p. 61.

9 Ibidem.

${ }^{10}$ H. Pohoska, Wstęp, w: J. Locke, Wybór pism pedagogicznych, Warszawa 1948, s. 16.
} 
go, Dwa traktaty o rzadzie, Listy o tolerancji, Racjonalność chrześcijaństwa oraz Myśli o wychowaniu.

\section{Wychowanie moralne według Locke'a}

Impulsem do rozważań pedagogicznych były dla Locke’a doświadczenia szkolne oraz te, które pozyskał w roli wychowawcy i nauczyciela, zaś okazją do ich wyrażenia stały się początkowo listy do Edwarda Clarke'a, będące odpowiedzią na jego prośbę o pokierowanie wychowaniem dzieci ${ }^{11}$. Treści, które zawarł Locke w listach, przywołał także w Myślach o wychowaniu ${ }^{12}$.

Z poglądami na temat edukacji w ścisłym związku pozostają, odzwierciedlone w pismach filozoficznych, przemyślenia na temat pochodzenia i granic ludzkiego poznania ${ }^{13}$. W Rozważaniach dotyczacych rozumu ludzkiego Locke twierdził, że umysł człowieka w chwili narodzin jest czystą tablicą (tabula rasa), którą, w ciągu życia jednostki, zapisuje doświadczenie ${ }^{14}$. $Z$ tego też powodu, duże znaczenie przypisywał wychowaniu i edukacji - stanowi ona integralną część procesu wypełniania umysłu treścią, a tym samym kształtowania człowieka. Locke podkreślał, że większość ludzi jest dobrymi lub złymi, pożytecznymi lub niepożytecznymi wskutek swego wychowania ${ }^{15}$. W rozważaniach Locke'a daje się więc zauważyć daleko idący optymizm pedagogiczny, wyrażający się przez przekonanie, że człowieka, niczym plastyczne tworzywo, można formować, uzyskując oczekiwany, pozytywny skutek.

Wychowanie postrzegał Locke jako zespół zabiegów zmierzających do ukształtowania człowieka pod względem fizycznym, moralnym i umysłowym. Te trzy płaszczyzny wychowania są ze sobą nierozerwalnie powiązane, jednakże najważniejszą spośród nich stanowi wychowanie moralne, którego celem jest takie pokierowanie rozwojem człowiekiem, ażeby potrafił on poddać swoje dążenia, pragnienia i skłonności kontroli i nakazom rozumu - umiejętności te, jak wskazywał Locke, stanowią podstawę cnoty ${ }^{16}$. Zdaniem Locke’a, powinno się bardziej cenić człowieka cnotliwego i mądrego, aniżeli uczonego. Wiedza sprzyja doskonaleniu ludzi szlachetnych, lecz w przypadku jednostek nieposia-

${ }^{11}$ L. Ward, The Role of the Public in Locke's Educational Writings, www.cpsa-acsp.ca/papers-2008/Ward. pdf [dostęp: 8.08.2014].

${ }^{12}$ M. Cullum, Augustine of Hippo and John Locke on Education, „Journal of Faith and the Academy” Vol. 1, No 2, 2008, p. 5.

13 J. Gianoutsos, Locke and Rousseau: Early Childhood Education, ,The Pulse” Vol. 4, No. 1, 2006.

${ }^{14}$ Ktokolwiek uważnie zbada stan dziecka zaraz po przyjściu jego na świat, nie będzie miat wielu powodów do przypuszczenia, iż umyst jego zaopatrzony jest $w$ wielki zasób idei stanowiacych materiat przyszłej jego wiedzy. Napetnia się nimi stopniowo [...]. J. Locke, O rozumie ludzkim, tłum. W.M. Kozłowski, Warszawa 1921, s. 90.

15 J. Locke, Myśli o wychowaniu, Wrocław-Kraków 1959, s. 6.

${ }^{16}$ Naczelna zasada i podstawa wszelkiej cnoty $i$ wartości leży $w$ tym, że człowiek jest zdolny wyrzec się swoich pragnień, przeciwstawić się własnym skłonnościom, a dążć jedynie ku temu, co rozum wskazuje jako najlepsze, chociaż chęć sktania w inną stronę. Ibidem, s. 27. 
dających dobrych skłonności może prowadzić do ich zepsucia. Z tego też powodu należy zdążać do zapewnienia dziecku wykształcenia, jednakże traktować je jako środek do pozyskania większych zalet. Locke zalecał więc, ażeby edukację dziecka powierzyć osobie, która dołoży starań o ukształtowanie jego wnętrza, będzie dbać o to, aby zabezpieczyć jego niewinność, żywić i pielegnować dobre, delikatnie poprawiać, a wypleniać w nim wszelkie złe skłonności i szczepić w nim dobre nawyki. To jest główny punkt, a skoro [... to zostanie zapewnione] można na dodatek ubiegać się o wiedzę ${ }^{17}$. Co ważne, zaszczepiane zasady nie mogą być uznawane przez jednostkę pozornie czy powierzchownie, lecz powinny prawdziwie wpisywać się w jej naturę. Jeżeli człowiek jest mądry i cnotliwy, to - twierdził Locke - zyska wielkość, dobre imię i szczęście; natomiast kiedy brakuje mu samodyscypliny, umiejętności poddawania swych skłonności władzy rozumu, prawdopodobnie nigdy niczego nie osiągnie. Cnota rozumiana jest przez Locke'a jako istotne dobro, do którego umocnienia we wnętrzu człowieka należy zmierzać tak długo, aż znajdzie [on] w niej prawdziwe upodobanie $i$ oprze na niej swa siłę, sławę i przyjemność ${ }^{18}$. Jaki jednak sposób postępowania, metody wychowawcze zalecał Locke, by ów cel skutecznie urzeczywistnić?

Według niego, proces wychowawczy należy rozpocząć jak najwcześniej, wtedy gdy dziecko potrafi zrozumieć przekazywane mu treści. Współczesny pedagog, Heliodor Muszyński, wskazuje na istnienie kilku faz rozwoju wrażliwości moralnej dziecka; pierwsza $\mathrm{z}$ nich (charakterystyczna dla okresu niemowlęctwa) określana jest jako stadium amoralizmu, w którym nie jest jeszcze ono zdolne do reagowania na sytuacje moralne, jednakże już w kolejnej fazie (heteronomii moralnej) zaczyna reagować na moralne elementy doświadczanych sytuacji; $w$ okresie tym dziecko jest podatne na wychowanie moralne ${ }^{19}$, zatem jest odpowiedni moment, by je rozpocząć, a pierwszym jego etapem, zdaniem Locke’a, uczynić należy ugruntowanie władzy rodzicielskiej. Locke wskazywał, że jeżeli od najmłodszych lat dzieci będą trzymane silna ręka, to [...] spokojnie sie jej poddadza $i$ będa uległe, ponieważ nigdy nie zaznaty innego traktowania ${ }^{20}$, a dzięki temu łatwiej będzie pokierować ich dalszym wychowaniem. Oddziaływanie opiekunów, hamulce i dyscyplina narzucane przez nich dzieciom, są szczególnie istotne i pożądane we wczesnym okresie ich życia, kiedy nie posiadają one jeszcze rozwiniętej zdolności sądzenia i panowania nad swymi zachciankami ${ }^{21}$.

W rozważaniach starożytnego, greckiego filozofa Epikura, szczególne miejsce zajmował pogląd, że istoty ożywione już od chwili narodzin dążą do przyjemności (dobro) i unikają cierpienia (zło); przyjemność stanowiłaby więc pierwsze i przyrodzone dobro

\footnotetext{
17 Ibidem, s. 151.

18 Ibidem, s. 60.

${ }^{19}$ H. Muszyński, Teoretyczne problemy wychowania moralnego, s. 67.

20 J. Locke, Myśli o wychowaniu, s. 35.

${ }^{21}$ [...] im młodsze sq dzieci, tym mniej należy ulegać ich niesfornym i niewłaściwym zachciankom, im mniej maja własnego rozumu, tym bardziej powinny być trzymane $w$ karbach i pozostawać pod absolutna władza tych, w czyich sa rękach. Ibidem, s. 33.
} 
oraz punkt wyjścia wszelkiego wyboru i unikania ${ }^{22}$. Podobna myśl pojawiła się i w refleksji pedagogicznej Locke'a ${ }^{23}$, który twierdził, że motywami skłaniającymi człowieka do określonego postępowania są dobro i zło, nagroda i kara, stąd też należy się do nich odwoływać, chcąc właściwie ukształtować osobowość dziecka ${ }^{24}$. Stosowanie odpowiednich nagród i kar jest więc niezbędnym instrumentem prawidłowej socjalizacji ${ }^{25}$.

Locke zauważał, że powszechnie funkcjonujący system nagród i kar nie jest właściwy, stąd też może spowodować więcej szkód, aniżeli korzyści. Jako jedno z negatywnych następstw nieodpowiedniego dyscyplinowania dziecka wskazywał możliwość, iż zbytnia surowość w karceniu może przyczynić się do pozbawienia dziecka temperamentu i chęci aktywności, czyniąc z niego osobę zbyt pokorną i niesamodzielną. Locke przestrzegał przed zbyt intensywnym naginaniem woli dzieci; według niego, jeżeli się ją nadmiernie upokarza, jeżeli się bardzo poniża i łamie ich charakter zbyt surowa ręka [...] traca one cała swoja siłę i dzielność [...a takie] dusze zniechęcone, lękliwe i uległe, dusze ospałe prawie nigdy nie daja się porwać i bardzo rzadko do czegoś dochodzą ${ }^{26}$. Ponadto dyscyplina osiągnięta nadmierną surowością może być tylko pozorna, gdyż z obawy przed karą dziecko będzie udawało posłuszeństwo, natomiast kiedy zagrożenie naganą nie będzie przez nie odczuwane, da ujście swoim naturalnym skłonnościom, które za pomocą kar cielesnych nie zostały wyeliminowane. Locke twierdził, że sankcje fizyczne zasadzają się na - uwyraźnianej już przez epikurejczyków - skłonności do unikania bólu i oddawania się przyjemności, a zatem nie sprzyjają wykluczeniu postawy uległości wobec namiętności, a wręcz ją intensyfikują; kara cielesna nie przyczynia się do opanowania naszego naturalnego popędu do oddawania się cielesnej $i$ chwilowej przyjemności i do unika za każda cenę przykrości, ale raczej podnieca ten popęd $i$ w ten sposób umacnia go w nas. To sa korzenie, z których wyrastaja wszystkie występne czyny i nieprawidłowości życia ${ }^{27}$. Uwzględniając wszelkie negatywne implikacje takiego działania, Locke sprzeciwiał się stosowaniu bicia jako metody mającej służyć dyscyplinowaniu dzieci ${ }^{28}$.

${ }^{22}$ Epikur, List do Menoikeusa, w: Diogenes Laertios, Żywoty i poglądy stynnych filozofów, X, 129, Warszawa 1982.

${ }^{23} \mathrm{~W}$ pracy Essays on the Law of Nature przyjemność i ból Locke umieścił w punkcie centralnym swej teorii motywacji; wskazywał, iż są one podstawowymi czynnikami warunkującymi działania ludzkie. Uczucia przyjemności i bólu towarzyszą podejmowaniu decyzji, myślom i działaniom człowieka. Locke’s Moral Philosophy, Stanford Encyclopedia of Philosophy, http://plato.stanford.edu/entries/locke-moral/. Snook I.A., John Locke's Theory of Moral Education, „Educational Theory”, Vol. 20, No 4, October 1970, p. 364.

24 J. Locke, Myśli o wychowaniu, s. 41.

${ }^{25}$ L. Ward, The Role of the Public.

26 J. Locke, Myśli o wychowaniu, s. 37.

27 Ibidem, s. 38.

${ }^{28}$ Locke czynił jeden wyjątek od tej zasady, twierdził mianowicie, że upór jest wadą, do usunięcia której trzeba niekiedy posłużyć się karą cielesną, ale powinno się jeśli to możliwe, urządzić to tak, aby wstyd z otrzymanych rózg, a nie ból, stanowił największa część kary. Wstyd, że się źle robi i zastuguje na karę, jest jedynym właściwym hamulcem, jaki przystoi cnocie. [...] Jeśli chcecie, by dzieci miały prawdziwie szlachetny charakter, to powinny one obawiać się raczej wstydu z popetnienia błędu oraz niesławy, jaka mu towarzyszy, aniżeli bólu. Ibidem, s. 68 . 
Przeciwny był również pozyskiwaniu określonego ich zachowania za pomocą nagród w postaci rzeczy, które sprawiają im przyjemność. Zauważał, że próby nakłonienia młodego człowieka do poskramiania żądań, folgowania swoim upodobaniom i zachęcanie go do właściwego postępowania przez oferowanie mu tego, czego pożąda, nie są niczym innym aniżeli tylko przyznaniem, że sa to rzeczy dobre, do których powinien dązyć29, umacnianiem go w ich pragnieniu. Postępowanie takie, w istocie rzeczy, polega na zastępowaniu jednego przedmiotu pożądania innym, jest ono spełnianiem zachcianek dziecka i w pewnym sensie potwierdzeniem, że są one słuszne. Uległość wobec skłonności dziecka, zaspokajanie jego pragnienia przyjemności (nawet tylko po to, by dzięki temu uzyskać pożądane zachowanie) staje się fundamentem, na którym stopniowo, acz systematycznie, budują się jego przyszłe wady, dla powstawania których jedyną przeszkodą jest właśnie ograniczanie jego pragnień i przyzwyczajanie do realizowania tylko tych celów, które jako słuszne wskazuje rozum. Dopóty, dopóki się tego nie osiągnie, nie można mówić o właściwym ukształtowaniu osobowości dziecka.

Locke twierdził, że ten kto znajdzie sposób, jak zachować duszę dziecka nieskrepowana $i$ wolna, a jednak jak równocześnie powstrzymać ja od wielu rzeczy, do których się skłania, i pociagnać do innych, które mu sa nie miłe, kto [...] umie pogodzić te pozorne sprzeczności, ten [...] posiadt prawdziwa tajemnicę wychowania ${ }^{30}$. Sam zalecał, ażeby zmienić system kar i nagród, w taki sposób, aby koncentrowały się one na sferze duchowej, nie zaś fizycznej. Jego zdaniem, czynnikami które najintensywniej oddziałują na ducha są szacunek i niesława; jeżeli uda się wszczepić dziecku miłość dobrego imienia i obawe przed wstydem i niesława, [...wpoi mu się...] prawdziwa zasadę, która stale będzie działać i nakłaniać je do dobrego ${ }^{31}$. Pozostaje jednak pytanie, w jaki sposób tego dokonać? Według Locke’a, szczególnego znaczenia nabiera konieczność doprowadzenia dziecka do zrozumienia, że ci, którzy postępują odpowiednio (dobrze), cieszą się szacunkiem i poważaniem innych, a w konsekwencji otrzymują to, co godziwe, zaś ludzie zachowujący się niewłaściwie (źle), spotykają się z pogardą i niechęcią, czemu towarzyszy deficyt tych dóbr, które dają zadowolenie i przyjemność. Zdaniem Locke’a, jeśli dzięki ciągłemu doświadczeniu dzieci dostrzegają, iż rzeczy sprawiające przyjemność przysługują tylko tym osobom, które posiadają dobrą opinię, to doprowadzi to do tego, że „przedmioty ich pragnień wystąpią jako towarzyszące cnocie. Jeżeli raz [...obudzi się...] wstyd z powodu ich błędów [...i jeżeli sprawi się...] że naucza się cenić przyjemność, jaka daje dobre imię, [...będzie można...] kierować nimi wedle upodobania, a one pokochaja wszystkie drogi cnoty ${ }^{32}$. Wynika z tego, że prawdziwą i najskuteczniejszą zaporą, powstrzymującą niewłaściwe skłonności dzieci, powinno być ich poczucie wstydu i obawa przed utrata dobrego imienia ${ }^{33}$, nie zaś kary odwołujące się do przykrych doznań fizycz-

\footnotetext{
${ }^{29}$ Ibidem, s. 40.

30 Ibidem, s. 37.

31 Ibidem, s. 42.

32 Ibidem, s. 43.

33 Według Locke'a dobre imię bliskie jest cnocie, aczkolwiek nie jest ono jej prawdziwa podstawa i jej miara [...]. Ponieważ zaś dobre imię jest pochlebnym świadectwem i pochwała, która rozum innych ludzi od-
} 
nych. Locke podkreślał, iż żadna sankcja nie będzie użyteczna dla dziecka, jeśli równocześnie wstyd i przykrość spetnienia zła nie oddziałuje na nie silniej niż sama kara ${ }^{34}$.

Zdawał sobie sprawę z istnienia różnić pomiędzy poszczególnymi jednostkami, dlatego też dużą wagę przypisywał do zindywidualizowania procesu wychowania. Postulował zatem połączenie znajomości psychologii z wychowaniem; zalecał, aby osoby, które zajmują się kształceniem dzieci najpierw zgłębiły ich naturę i zdolności, ażeby starały się dostosować sposoby kształcenia do możliwości i poziomu rozumienia wychowanków, ponieważ różnorodność charakterów dzieci sprawia, iż z trudnościa można by znaleźć dwoje dzieci, do których by można zastosować dokładnie tę sama metodę ${ }^{35}$. Fakt istnienia znaczących różnic $\mathrm{w}$ temperamencie i usposobieniu dzieci, powoduje że niektóre spośród nich mogą być bardziej podatne na niekorzystne wpływy, aniżeli inne, stąd też wnikliwa obserwacja i stosowna reakcja opiekunów mogą przed nimi w porę uchronić.

Locke akcentował rolę przykładu postępowania moralnego w kształtowaniu osobowości dzieci; podkreślał, że żadne słowa nie moga im dać tak jasnego zrozumienia cnót $i$ występków, jak im to okaża uczynki innych ludzi [...] z pewnościa wstydzić się będa $i$ znienawidza one każde zło, którego się dopuścity przez przeoczenie lub w którym sobie pofolgowaty, gdy im je pokażemy u drugich ${ }^{36}$. Owa wytyczna Locke'a wpisuje się w ramy metody modelowania, polegającej na przyswajaniu określonych postaw w drodze powielania zachowań innych ludzi, mających tym większy wpływ na jednostkę, im większym cieszą się oni autorytetem i im bardziej szczerzy są w swoim postępowaniu. Locke, zalecający rodzicom wyrabianie sobie autorytetu już od najwcześniejszych lat życia dziecka, dostrzegał siłę wpływu ich przykładu na kształtowanie jego postaw, stąd też przestrzegał rodziców przed przejawianiem przy dzieciach zachowań, co do których nie chcieliby, ażeby były przez dzieci naśladowane. Odradzał także zbywanie pytań dzieci kłamliwymi odpowiedziami, ponieważ nie dość, że łatwo zauważą, iż są zwodzone, to idąc za przykładem dorosłych same zaczną lekceważyć i oszukiwać innych, a zatem zbywanie dziecka kłamstwem nie doprowadzi do niczego innego, jak tylko rozwinięcia w nim jednej z najgorszych przywar, która jest matka tylu złych postępków, [...] że należy wychowywać dziecko $w$ największej możliwej doń odrazie ${ }^{37}$.

Locke, przeciwnie aniżeli np. Arystoteles ${ }^{38}$ (384-322 p.n.e.), był zdania, że rodzina jest najbardziej właściwym dla dziecka środowiskiem wychowawczym, w wyniku czego przedkładał wychowanie i kształcenie w domu, pod kierunkiem rodziców oraz starannie

daje, jakby za wspólnym porozumieniem, cnotliwym i prawym postępkom, przeto jest ono dla dzieci właściwym przewodnikiem $i$ zachęta do czasu, kiedy będa mogly same sądzić i własnym rozumem rozstrzygać, co jest rzecza właściwa. Ibidem, s. 45.

34 Ibidem, s. 38.

35 Ibidem, s. 217.

36 Ibidem, s. 73-74.

37 Ibidem, s. 134.

${ }^{38}$ Zdaniem Arystotelesa, będącego zwolennikiem wychowania do życia w państwie, jeżeli państwo ma tylko jeden cel, więc $i$ wychowanie musi być jedno i to samo dla wszystkich, i państwo jako całość musi wziąć troske o nie na siebie, a nie osoby prywatne, jak to bywa dzisiaj, kiedy każdy z osobna troszczy się o swe dzieci $i$ wedtug swego upodobania prywatnie im nauki udziela. [...] wychowanie musi być uregulowane $w$ drodze 
dobranego nauczyciela, ponad edukację w szkole, gdzie młody człowiek miałby kontakt z niewłaściwie wychowaną i nieposiadającą stosownych obyczajów młodzieżą, której przykład mógłby wywierać zły wpływ i z czasem doprowadzić do upadku moralnego.

Rola nauczyciela, zdaniem Locke'a, nie może sprowadzać się wyłącznie do przekazywania wiedzy naukowej, lecz polegać również na wskazywaniu własnym przykładem, w jaki sposób należy postępować. $Z$ tego też powodu nauczycielowi obcy być musi dysonans pomiędzy wskazówkami przekazywanymi dziecku a faktycznie prezentowaną postawą; nie ma żadnego celu, by nauczyciel mówit o powściaganiu namiętności, skoro sam puszcza niektórym wodze i na próżno będzie usiłowat naprawić u swego wychowanka jakiś nałóg czy nieprzystojność, na którą sam sobie pozwala. Jest rzecza pewna, że złe przykłady silniej pociagaja aniżeli dobre maksymy, dlatego musi on również troskliwie ochraniać go od wpływu złych wzorów ${ }^{39}$. W obszar powinności nauczyciela włączał Locke również zaznajomienie młodego człowieka z zagrożeniami, jakie może spotkać w świecie; ze sposobami postępowania ludzi, manipulacjami do jakich są zdolni, aby osiągnąć swój cel oraz wyposażenie podopiecznego w umiejętność rozpoznawania ich rzeczywistych intencji - wszystko to służyć ma zabezpieczeniu jego cnoty i uchronić przed nieszczęściem. Nauczyciel powinien oddziaływać na swego ucznia w bardzo szerokim zakresie; jego zadaniem jest ułożyć zachowanie się $i$ uformować umyst swego wychowanka, zaszczepić mu dobre przyzwyczajenia i zasady cnoty i madrości, dawać mu po trochu pogląd na ród ludzki i wyrobić $w$ nim miłość $i$ chęć naśladowania tego, co doskonate i godne pochwały oraz wlać mu silę, dzielność $i$ wytrwałość $w$ tym dążeniu. [...] dobrego wychowania, znajomości świata, cnoty, pilności i miłości dobrego imienia [podopieczny nigdy] nie może mieć zbyt wiele ${ }^{40}$.

Jako że niesprawiedliwość i niegrzeczność wypływają zazwyczaj z nadmiernej miłości do siebie samego, wychowaniu dobrego, uczciwego człowieka sprzyjać będzie, zdaniem Locke'a, uczenie szacunku i uprzejmości dla innych, co czynić należy drogą przyzwyczajania do właściwych zachowań. Jeżeli natomiast dopuści się do tego, by dziecko nieodpowiednio traktowało innych, może to z czasem doprowadzić do sytuacji, że taka postawa spowszednieje, rozwinie się w pogardę dla drugiego człowieka, a skończy prawdopodobnie na pognębieniu innych i na okrucieństwie ${ }^{41}$. Locke zalecał zatem wpajanie i rozwijanie uczuć humanitarnych już od najmłodszych lat. Jego zdaniem, dziecko powinno być uczone i przyzwyczajane do okazywania współczucia i uczuć życzliwych nie tylko innym ludziom, ale wszelkim żywym stworzeniom; należy więc wychowywać dzieci $w$ odrazie do zabijania lub dręczenia jakiegokolwiek żyjącego stworzenia i należy je nauczyć nie niszczyć ani nie burzyć niczego, chyba że się to dzieje dla utrzymania lub pożytku czegoś szlachetniejszego, [...] należy ludzi przyzwyczajać do lagodności dla wszystkich stworzeń obdarzonych czuciem i do tego, by niczego w ogóle nie niszczyć i nie

prawa $i[\ldots]$ przeprowadzić powinno je państwo. Arystoteles, Polityka, thum. L. Piotrowicz, Warszawa 1953, ks. I, roz. 1.

39 J. Locke, Myśli o wychowaniu, s. 79.

40 Ibidem, s. 90.

${ }^{41}$ Ibidem, s. 122 
marnować. [...] zamiast tego ustalać i podsycać przeciwna i bardziej naturalna skłonność do łagodności i współczucia ${ }^{42}$.

\section{Aktualność myśli pedagogicznej Locke’a}

We współczesnym świecie niestety coraz częściej daje się zaobserwować deficyt współczucia i życzliwości, obojętność, odwrócenie od postawy humanizmu, dominację agresji i okrucieństwa, brak szacunku dla innych, egoizm, niepohamowaną dążność do przyjemności, wandalizm oraz otwarte negowanie lub obojętność wobec wartości i norm moralnych. Jeżeli, zgodnie z Locke'm, uznać, że to, jakim jest człowiek, wynika z wychowania, jakiemu został poddany, to nasuwa się prosty wniosek, iż zaistniała sytuacja jest implikacją błędów popełnionych w działalności wychowawczej. To z kolei wiedzie do przekonania, że konieczne jest dokonanie w niej istotnych zmian.

Czy jednak postulaty Locke'a, zawarte w ramach jego koncepcji wychowania moralnego, mogłyby okazać się pomocne w realizowaniu tego zadania? Celem kształcenia moralnego jest wprowadzenie dziecka w świat wartości, uwyraźnienie zasad właściwego postępowania, które nie są mu jeszcze znane. To właśnie zapewnić ma koncepcja Locke’a - wskazuje co, i w jaki sposób, powinno być osiągnięte w następstwie oddziaływania wychowawczego. Locke postulował traktowanie dzieci, jak jednostek rozumnych, przyuczanie ich, od najwcześniejszych już lat życia, do okazywania życzliwości wszystkim istotom odczuwającym, powstrzymywania nieodpowiednich skłonności i pragnień. Niepodważalną zaletą koncepcji Locke'a jest także położenie silnego akcentu na potrzebę znajomości psychiki dziecka, a w konsekwencji zindywidualizowania procesu wychowania, dostosowania metod kształcenia do dziecka, nie zaś wpasowywania go w ramy już istniejącego, $\mathrm{z}$ góry ustalonego schematu.

Podobnie jak czynił to Locke, również współcześnie podkreśla się, i to coraz częściej, że młodym ludziom należy ukazywać wartość życzliwości, prawdy i odpowiedzialności, piętnując jednocześnie wady, postawy i zachowania niemoralne. Może to bowiem przyczynić się do przeciwdziałania chaosowi moralno-etycznemu, który wkradt się do rodzin i szkót. [...powodując, iż...] dziecko znajduje się pod sprzecznymi oddziaływaniami ze strony rodziców, szkoły, mediów i środowiska, które lansuja nawzajem wykluczajace się wartości i normy, postawy i zachowania, cele i ideaty ${ }^{43}$, co wpływa negatywnie na rozwój osobowości dziecka, w którym budzi się nieufność w szczerość i autentyczność zasad panujacych $w$ wychowaniu ${ }^{44}$. Trzeba zgodzić się, że wielostronne, i nie zawsze kompatybilne oddziaływanie na dziecko rzeczywiście może powodować u niego zamęt dotyczący świata wartości i zasad moralnych, stąd też - jako że we wczesnym okresie życia zazwyczaj największym autorytetem są rodzice, to przede wszystkim oni powinni właściwie pokierować jego rozwojem moralnym, a ich zachowanie powinno być przykładem for-

\footnotetext{
${ }^{42}$ Ibidem, s. 119-120.

43 A.E. Szołtysek, Filozofia wychowania moralnego, Impuls, Kraków 2009, s. 217.

${ }^{44}$ K. Murawski, Rozwój $i$ wychowanie moralne dzieci i młodzieży, „Collectanea Theologica” 50/1, 1980.
} 
mującym postawy moralne dzieci. Podobnie widział tę kwestię i Locke, którego teoria pedagogiczna określa nie tylko cel i sposób wychowania dziecka, lecz w pewien sposób stosuje się także do jego rodziców oraz opiekunów. Podkreślając bowiem znaczenie przy$k \nmid a d u$ w kształtowaniu charakteru i osobowości młodego człowieka, wymagał Locke określonego postępowania i od jego otoczenia. Rodzice pragnący wychować potomka na człowieka cnotliwego, powinni wspierać się przede wszystkim własnym przykładem, a zatem z konieczności być ludźmi cnotliwymi. Nie da się jednak ukryć, że nie zawsze środowisko rodzinne, w którym wychowuje się dziecko, posiada rozeznanie w świecie wartości i stosowną świadomość moralną, przez co nie jest dla niego odpowiednim źródłem do czerpania wzorów do naśladowania. Szczególnie w takiej sytuacji pomocny powinien być wpływ nauczycieli przedszkolnych i wczesnoszkolnych, których zadaniem jest uwrażliwianie dziecka na wartości uniwersalne oraz zaznajamianie $\mathrm{z}$ faktem, iż przez niektórych są one, niesłuszne, negowane. Rola nauczyciela byłaby więc zbieżna $\mathrm{z}$ tą, którą przewidywał Locke dla wychowawcy domowego - zaznajomienie dziecka z cnota, z jej zagrożeniami oraz nauczenie obrony uznawanych wartości i zasad.

W przypadku dzieci starszych, a więc posiadających bardziej rozwinięty intelekt i umiejętność wnioskowania, należałoby także rzetelnie i dogłębnie wyjaśnić, dlaczego niektórzy ludzie negują zasady moralne i dlaczego jednak trzeba się do nich stosować.

Rozbieżności w treści przekazów o charakterze moralnym, które odbierają dzieci i młodzież, mogą stanowić przyczynę nieumiejętności określenia przez nie, jakie zachowanie faktycznie jest właściwe i prowadzić do zachowań nieakceptowanych. Trzeba jednak uwzględnić i taką możliwość, że młody człowiek posiada świadomość, jakie zachowanie w społeczeństwie uznawane jest za słuszne czy też dobre, ale z określonych względów postępuje inaczej. Być może nie zawsze to, co jest traktowane jako dobre z uwagi na innych, jest takim i dla niego, zatem skłania się do wyboru takiej opcji, która jest bardziej korzystna dla niego. Ponadto, w dzisiejszym świecie, często trudniej jest postępować w zgodzie z zasadami moralnymi - wymaga to większego wysiłku, a niekiedy naraża nawet na nieprzyjemności (np. interwencja w przypadku stosowania przemocy wobec innej osoby może skutkować pobiciem interweniującego); jeśli zatem bycie dobrym jest trudniejsze, aniżeli bycie złym i może wiązać się z doznaniem jakieś przykrości - po cóż więc się starać? Młody człowiek może uważać, że korzystniej jest działać w taki sposób, który jemu przysparza mniej przykrości lub daje więcej przyjemności. Prawdopodobnie spotyka się on z opinią, iż jego zachowanie jest niewłaściwe, a jej uzasadnieniem jest najczęściej odniesienie do określonej straty, którą wskutek jego działania ponosi inny, zewnętrzny podmiot (pobity czy okradziony człowiek, poniżona koleżanka/ kolega z klasy, właściciel zniszczonego dobra materialnego itp.); dość często słyszy więc, że nie powinien szkodzić innym (nawet jeśli wiązałoby się to z jakąś korzyścią dla niego), lecz rzadziej - dlaczego; czemu miałby uwzględniać przy podejmowaniu działania dobro innych, zamiast ulegać własnym zachciankom, zwłaszcza jeśli nie grozi mu za to żadna poważniejsza sankcja?

W koncepcji wychowania moralnego Locke'a skłonność jako punkt wyjścia dla dokonywania wyboru jest nie do przyjęcia, a wyrzeczenie się pragnień i skłonności oraz dążenie ku celom wskazanym przez rozum, wbrew chęciom, jest świadectwem cnoty. 
Czy jednak młody człowiek nie może uznawać, iż to właśnie kierowanie się ku temu, co dla niego miłe, przyjemne, „fajne” jest zgodne z rozumem? Zapewne jest to możliwe. Jednakże, odwołując się do koncepcji Locke'a, można pokazać, że postępowanie determinowane popędami wydaje się być „rozumne” tylko na krótką metę. Locke wskazywał, że ograniczanie swoich chęci przez człowieka jest korzystne nie tylko z uwagi na społeczeństwo, lecz przede wszystkim dla niego samego. Pisał, że Bóg połaczył nierozerwalnie cnotę ze szczesściem ogółu i uczynił jej petnienie niezbędnym dla zachowania społeczeństwa i jawnie dobroczynnym dla wszystkich, z którymi ma do czynienia człowiek cnotliwy, nie należy się dziwić, że każdy nie tylko przystaje na te prawidła, których spetnienie zaręcza mu korzyść, lecz także zaleca je i zachwala innym. Zarówno z przekonania, jak $i$ z interesu własnego może je uważać za święte; gdyby bowiem byty pogardzone i pogwatcone, nie bytby sam bezpieczny ${ }^{45}$. Podobną myśl odnaleźć można także w filozofii Sokratesa (469-399 p.n.e.) i Immanuela Kanta (1724-1804). Pierwszy z filozofów wskazywał, że żaden człowiek nie chce doświadczać tego, co złe, a jak powszechnie wiadomo źli ludzie źle robia swemu najbliższemu otoczeniu, a dobrzy dobrze. [...] jeśli kogoś w swym otoczeniu złym człowiekiem zrobię, moge potem sam czegoś doznać złego $z$ jego strony $[\ldots]^{46}$. Kant $\mathrm{z}$ kolei zobowiązywał do postępowania $\mathrm{w}$ taki sposób, co do którego można chcieć, by stał się on prawem powszechnym; innymi słowy, człowiek podejmując lub zaniechując działania powinien zapytać siebie, czy chciałby, aby zasada jego postępowania była stosowana przez ogół? Czy, nie stosując się do zasad moralnych, faktycznie chciałby, by inni czynili podobnie? Według Kanta udzielenie odpowiedzi twierdzącej przez jednostkę, implikowałoby powstanie sytuacji, w której nie tylko inni, lecz i ona sama, mogliby być narażeni na poważne przykrości ${ }^{47}$.

Podobnie i w koncepcji Locke'a zawiera się przekonanie, że kierowanie się chęciami, uleganie zwierzęcym skłonnościom, nie tylko prowadzi do szkody innych, lecz w dłuższej perspektywie szkodzi i samemu sprawcy danego działania. Kiedy człowiek jest młody, pełen energii może na pewnych obszarach dominować nad innymi, zwłaszcza słabszymi jednostkami, jednakże owa potencja nie jest predykatem trwale przynależnym bytowi ludzkiemu, stąd też warto konfrontować młodych ludzi z pytaniem, czy wówczas,

45 J. Locke, O rozumie ludzkim, s. 48.

46 Platon, Obrona Sokratesa, w: Platon, Dialogi, Warszawa 1993, s. 191-192.

47 Aby dokładniej wyjaśnić swoją myśl, Kant odwoływał się do przykładów - to jeden z nich: [...] komu dobrze się wiedzie, widząc, ̇̇e inni (którym mógłby przecież dopomóc) musza walczyć z wielkimi trudnościami, myśli sobie: co mnie to obchodzi? Niech każdy będzie tak szczęśliwy, jak Bóg zechce, albo jak sam potrafi; niczego mu nie odbiorę ani nawet niczego nie będę mu zazdrościł, nie mam tylko żadnej chęci przyczyniać się do jego powodzenia lub wspomagać go w biedzie! W istocie, gdyby taki sposób myślenia stat się ogólnym prawem przyrody, mógłby ród ludzki bardzo dobrze istnieć, a nawet bez watpienia jeszcze lepiej, aniżeli wtedy, kiedy każdy plecie o współczuciu i życzliwości, a nawet przy okazji usituje petnić coś i podobnego, natomiast, gdzie tylko może, oszukuje, prawa ludzi sprzedaje lub je $w$ inny jakiś sposób narusza. Jednak chociaż jest możliwe, że wedlug owej maksymy ogólne prawo przyrody mogłoby istnieć, to jednak nie jest możliwe chcieć, żeby taka zasada posiadała wszędzie znaczenie prawa przyrody. Albowiem wola postanawiajaca to, sprzeciwiałaby się sama sobie, ponieważ może się przecież zdarzyć niejeden taki wypadek, $w$ którym człowiek ten potrzebuje miłości $i$ wspótczucia drugich, a w którym przez, takie prawo wynikające z własnej jego woli, pozbawiłby sam siebie wszelkiej nadziei pomocy, której sobie życzy. I. Kant, Uzasadnienie metafizyki moralności, Kęty 2001, s. 40-41. 
gdy osłabnie ich witalizm, chcieliby być otoczeni ludźmi postępującymi w taki właśnie sposób, jak oni obecnie?

Locke podkreślał też, że pożądanym byłoby wskazywanie wychowankowi, że warto być dobrym człowiekiem, ponieważ tylko tacy ludzie otrzymują to, co godziwe, zaś ludzie postępujący źle pozbawieni są tego, co daje zadowolenie i przyjemność. Współcześnie jednak zrealizowanie tego postulatu może nie być łatwe, ponieważ życie coraz częściej zdaje się zaświadczać o czymś przeciwnym - znane są choćby przypadki, kiedy to człowiek broniący się przed agresorem może podlegać poważniejszym sankcjom, aniżeli napastnik, ponieważ w akcie samoobrony przyczynił się do jego szkody ${ }^{48}$.

Warto także wspomnieć, że dość często jednostka nieprzejawiająca w młodości szacunku dla wartości i zasad moralnych wraz z osiąganym wiekiem zaczyna się do nich stosować, ale nie można jednak wykluczyć możliwości, iż postępuje zgodnie z regułami moralnymi, ponieważ jest to dla niej w jakiś sposób korzystne, jednakże nie wypływa z jej faktycznych przekonań - stąd też szczególnie istotne staje się zalecenie Locke'a, by tak pokierować wychowywaniem dzieci, aby moralność nie byla tylko parawanem skrywajacym ich prawdziwa naturę, lecz jej rdzeniem.

Ukształtowanie moralne niewątpliwie stanowi implikację oddziaływania różnych podmiotów - rodziny, szkoły, rówieśników, kościoła czy mediów. Podstawowym jednak środowiskiem wychowawczym wywierającym wpływ na kształtowanie osobowości moralnej dzieci i młodzieży jest rodzina. Podkreślał to również Locke, który postulował, by rodzice jak najwcześniej zaczęli budować i umacniać swój autorytet, dzięki czemu zintensyfikują wpływ wychowawczy na dziecko. Niestety, współcześnie dość często daje się zaobserwować dewaluację owego pozytywnego oddziaływania, co być może stanowi negatywne następstwo niewystarczającej ilości czasu poświęcanego dziecku, postępującej tolerancji dla nieodpowiednich jego zachowań, zbyt rozwiniętego partnerstwa w relacjach z dziećmi ${ }^{49}$, hipertrofii postaw konsumpcyjnych rodziców czy niewłaściwych stosunków w rodzinie.

Coraz częściej zdarza się też, że rodzice przerzucają obowiązki wychowawcze na inne podmioty, przede wszystkim nauczycieli, oczekując jak najlepszych efektów. Locke dostrzegał, że nauczyciel ma duży wpływ na kształtowanie się systemu wartości młodych ludzi, stąd stawiał przed nim wysokie wymagania, które na pozór mogą wydawać się nawet zbyt wygórowane, faktycznie jednak nie odbiegają zbytnio od oczekiwań, jakie współcześnie rodzice zgłaszają wobec pedagogów szkolnych - czegóż bowiem Locke żada od nauczyciela? Oto, by byt człowiekiem nie tylko wykształconym, ale także głęboko moralnym, by rozumiat i potrafit obserwować dziecko powierzone swojej

${ }^{48} \mathrm{Na}$ fakt, że zdarza się, że napastnik pozostaje bezkarny w przeciwieństwie do człowieka broniącego się, zwracał uwagę m.in. Tadeusz Kotarbiński, który pisał, iż należy Zasłaniać napastowanych, rozbijać napastników. Tam się ustala pokojowy modus vivendi, gdzie obrona dzielniejsza jest od napadu. A wolno mniemać, że $w$ działaniach obronnych nie dopatrza się występku ci, których prawo powotuje do zapobiegania napaści. T. Kotarbiński, Konieczność samoobrony, w: T. Kotarbiński, Pisma etyczne, Ossolineum, Wrocław-WarszawaKraków-Gdańsk-Łódź 1987, s. 333.

${ }^{49}$ Zdaniem Szołtyska lansowanie partnerstwa między rodzicami i ich dziećmi spowodowało radykalne obniżenie rangi rodziców jako przewodników życiowych dla dziecka. A.E. Szołtysek, op. cit., s. 219. 
opiece, by potrafit dostosować swoje metody do jego zainteresowań, a przede wszystkim, by potrafił oddziaływać na nie swym osobistym przykładem ${ }^{50}$. Również i dziś wychowawca powinien być człowiekiem obeznanym ze światem wartości i odwołującym się do nich w procesie kształtowania osobowości swego podopiecznego. Rodzic zazwyczaj pragnie, by edukacja szkolna wpłynęła na uformowanie jego dziecka na kulturalnego, asertywnego, wszechstronnego człowieka, a jednocześnie niejednokrotnie nie współdziała w wystarczającym stopniu w przeprowadzaniu tego procesu z wychowawcami szkolnymi, niekiedy nawet go zakłóca - dając nieodpowiedni przykład, tolerując wybryki dziecka, czy wreszcie podważając autorytet nauczycieli, którzy mają przyczyniać się do prawidłowego rozwoju moralnego (i umysłowego) dzieci. Wystarczy choćby przejrzeć Internet, do którego dzieci często mają swobodny dostęp, by natknąć się na szereg niepochlebnych, negatywnych opinii kierowanych pod adresem środowiska nauczycielskiego. Jeżeli młody człowiek będzie stykał się z tego rodzaju poglądami, nauczycielowi, który ma go kształtować, będzie dużo trudniej wyrobić i utrzymać autorytet. Skoro zaś słabnie oddziaływanie rodzica, nauczyciela, to powstanie luka, którą stopniowo wypełniają rówieśnicy, bohaterowie (niekoniecznie pozytywni) filmów czy gier. Locke dostrzegał, jakim zagrożeniem jest podważanie autorytetu osób, które mają pozytywnie kształtować dziecko; pouczał, że aby utrzymać powage [wychowawcy] wobec wychowanka, oprócz zatajenia, że nie ma on prawa używania rózgi [...przynajmniej dotąd, dopóki nie doświadczysz jego rozwagi i temperamentu...], musisz sam bezwzględnie odnosić się do niego z wielkim szacunkiem [...] Nie możesz bowiem oczekiwać, że twój syn będzie miat szacunek dla tego, kogo, jak widzi, [...ojciec] czy jego matka, czy inni lekceważą ${ }^{51}$.

\section{Zakończenie}

Myśli o wychowaniu konstruował Locke, mając na uwadze stosowne wychowanie chłopców z zamożnych rodzin, jednakże postulowane przez niego zasady moralne w rzeczywistości nie ograniczają się wyłącznie do nich; mają one ponadczasowy, uniwersalny charakter, mogą więc stanowić wskazówkę, w jaki sposób zadbać o rozwój moralny każdego dziecka. Teoria wychowania moralnego Locke'a przeniknięta jest głębokim humanitaryzmem; a z perspektywy czasów współczesnych, szczególnie aktualna wydaje się podkreślana przez niego konieczność uczenia młodych ludzi szacunku wobec drugiego człowieka, odrzucenia i potępienia przemocy oraz okrucieństwa także wobec braci mniejszych. Zasady moralnego postępowania powinny być przekazywane przede wszystkim w rodzinie, ale również i szkole, głównie na lekcjach etyki i religii, choć nie tylko, gdyż każdy nauczyciel powinien je uwyraźniać własnym przykładem.

Zamiarem Locke'a było wskazanie metody wiodącej do wychowania ludzi cnotliwych, roztropnych, wykształconych, o dobrym zachowaniu, a więc do urzeczywistnienia

\footnotetext{
${ }^{50}$ K. Mrozowska, Wstęp, w: J. Locke, Myśli o wychowaniu, s. XLVIII.

51 J. Locke, Myśli o wychowaniu, s. 78.
} 
celu, który chyba nigdy nie straci na aktualności, gdyż przyszłość społeczeństw zależy od tego czy potrafią moralnie wychować kolejne pokolenia.

\section{Bibliografia}

Aldrich R., John Locke (1632-1704), „Prospects: the quarterly review of education”, Vol. 24, No. 1/2, 1994, p. 61-76.

Arystoteles, Polityka, thum. L. Piotrowicz, Warszawa 1953.

Brezinka W., Wychowanie i pedagogika $w$ dobie przemian kulturowych, Wydawnictwo WAM, Kraków 2005.

Cullum M., Augustine of Hippo and John Locke on Education, „Journal of Faith and the Academy", Vol. 1, No 2, 2008, p. 5-12.

Epikur, List do Menoikeusa, w: Diogenes Laertios, Żywoty i poglądy stynnych filozofów, X, 129, PWN, Warszawa 1982.

Gianoutsos J., Locke and Rousseau: Early Childhood Education, „The Pulse”, Vol. 4, No. 1, 2006.

Homplewicz J., Etyka pedagogiczna, Wydawnictwo Salezjańskie, Warszawa 2000.

Kant I., Uzasadnienie metafizyki moralności, Wydawnictwo Antyk, Kęty 2001.

Klimowicz E., Wartość, w: Stownik etyczny, red. S. Jedynak, Lublin 1990, s. 258.

Kotarbiński T., Konieczność samoobrony, w: T. Kotarbiński, Pisma etyczne, Ossolineum, WrocławWarszawa-Kraków-Gdańsk-Łódź 1987, s. 331-333.

Łobocki M., Altruizm w wychowaniu, Wydawnictwo Uniwersytetu Marii Curie-Skłodowskiej, Lublin 2002.

Locke J., Myśli o wychowaniu, PAN, Wrocław-Kraków 1959.

Locke J., O rozumie ludzkim, thum. W.M. Kozłowski, Warszawa 1921.

Locke's Moral Philosophy, Stanford Encyclopedia of Philosophy, plato.stanford.edu/entries/ lockemoral/, [dostęp: 08.08.2014].

Mariański J., Kryzys moralny czy transformacja wartości? - studium socjologiczne, Towarzystwo Naukowe KUL, Lublin 2001.

Mrozowska K., Wstęp, w: J. Locke, Myśli o wychowaniu, PAN, Wrocław-Kraków 1959.

Murawski K., Rozwój i wychowanie moralne dzieci i młodzieży, „Collectanea Theologica” 50/1, 1980.

Muszyński H., Rozwój moralny, WSiP, Warszawa 1983.

Muszyński H., Teoretyczne problemy wychowania moralnego, Państwowe Zakłady Wydawnictw Szkolnych, Warszawa 1965.

Platon, Obrona Sokratesa, w: Platon, Dialogi, Unia Wydawnicza VERUM, Warszawa 1993.

Pohoska H., Wstęp, w: J. Locke, Wybór pism pedagogicznych, Państwowe Zakłady Wydawnictw Szkolnych, Warszawa 1948.

Róg A., Orzechowska M., Wychowanie do wartości, „Edukacja i Dialog” 5, 2004, s. 12.

Snook I.A., John Locke's Theory of Moral Education, „Educational Theory”, Vol. 20, No 4, 1970, p. 364-367.

Szołtysek A.E., Filozofia wychowania moralnego, Impuls, Kraków 2009.

Ward L., The Role of the Public in Locke's Educational Writings, www.cpsa-acsp.ca/papers-2008/ Ward.pdf, [dostęp: 08.08.2014]. 